\title{
Study on the Cultural Heritage and Tourism Management Methods
}

\author{
Yue $\mathrm{Li}^{1, \mathrm{a}}$, Hong Wang ${ }^{2, \mathrm{~b}}$ \\ 1, 2 Qingdao Huanghai University, Qingdao, 266427 \\ a email, ${ }^{b}$ email,
}

\section{Keywords: Cultural Heritage, Tourism Management, Social Development}

\begin{abstract}
China is a big country in the world heritage, the number of world heritage has ranked third in the world. In 2004, in a way, is China's World Heritage Year: 28th session of the World Heritage Committee held in Suzhou, the south gate of Pingyao ancient city walls collapsed, the Forbidden City Beijing six World Heritage ticket prices, which once again making a series of events World Heritage become the focus of public and media attention, expand the discussion. For these discussions we objectively look inscription boom, reform and improve the management system and mode of operation of existing world heritage, develop appropriate legal regime has very important significance. But the theory of world heritage is still out of touch with the reality of the world heritage sites causing serious damage. As in recent years a growing recognition of the World Heritage, in this subject more and more research and attention. From existing domestic literature, heritage studies focused on understanding the value of heritage, heritage resources, heritage tourists law, heritage tourism and heritage conservation impact and planning. But there is still no system of heritage protection and tourism development discussion papers or monographs. On a practical level, there is no heritage can use operating system. Therefore, this paper will focus on the process of world cultural heritage protection and tourism development research, it aims to establish a complete system, to change the current number of domestic Heritage inadequate protection, management confusion.
\end{abstract}

\section{Introduction}

Since the World Cultural and Natural Heritage Convention, signed in 1985 and 1987 of the first batch of six heritage sites listed in the World Heritage List, China has inscribed on the World Heritage List of the total number of ranked third in the world heritage sites. With the increase in the number of World Heritage, the community of world heritage protection and utilization has more attention. September 22, 1985, the Standing Committee of the National People's Congress of the thirteenth meeting of the sixth ratified the World Heritage Convention, making China the first 89 parties to the Convention. After that, many of the officers elected to the World Heritage Committee, plays an important role in the cause of world heritage.

China's world heritage declaration heat began in the last century. Originally known Pingyao and Lijiang Old Town was inscribed on the World Heritage List because of fame, and soon became a new tourist destination, creating a pleasant surprise for money. In this demonstration effect, declared World Heritage enthusiasm around the abnormal high, now included in the World Heritage Tentative List of World Heritage national project on the already over a hundred. Indeed, as a long history and splendid culture of the country, China has been inscribed on the World Heritage List of heritage and its rich heritage of the number of actual gap, around the inscription boom after another seems reasonable. But it is worth noting that it shares the inscription boom there is an underlying bias awareness and motivation on the dislocation. Inscribed on the World Heritage List, not only means honor and reputation, but also to assume greater responsibilities and obligations, many people only noticed the former while ignoring the latter.

In 2004, in a way, is China's World Heritage Year: 28th session of the World Heritage Committee held in Suzhou, the south gate of Pingyao ancient city walls collapsed, the Forbidden City Beijing six World Heritage ticket prices, which a series of events once again made the world heritage and become the focus of public attention in the media, launched a major discussion. These discussions 
for us to objectively look at the inscription boom, reform and improve the management system and mode of operation of existing world heritage, develop appropriate legal regime has very important significance. China is a big country in the world heritage, but it is also big developing countries, the burden of huge heritage protection and the limited financial capacity of contradictions still exist, how to effectively protect the good development of the economy of these precious and fragile world heritage, witch is a problem to be solved, we can no longer stay in the appeal, discussion and waiting.

Cultural and natural heritage is not an ordinary asset, nor is the general sense of economic resources, and they are once the World Heritage List, it means that the estate has become a worldwide public assets, the applicant countries have made to protect the mankind a world heritage of commitment. In reality, however, how to seek a reasonable property between the priorities and the right combination of points, especially in the face of market forces impact penetration and economic development, how to find an accurate position between the different attributes, how by organizing and scientific institution building, effectively ensure the rational exert the functions described above, these issues are still unresolved. Theoretically clear and simple, but it can not solve the complex and contradictory reality.

Some local governments enamored inscription activities, often are not concerned about the commitment and the responsibility to protect, but huge economic expectations. Dislocation applicant's motivation and intent between the approval, but also for the future protection and management laid a great deal of risk.

Through rational planning, scientific management, heritage conservation and tourism development is not completely contradictory. But the fact is: on the one hand people held aloft the banner of sustainable development and protection, on the other hand has no choice but to witness the destruction caused by excessive commercial development; the one hand, people condemned the over-exploitation of heritage, on the other hand they can not find to other more sustainable protection and use of the method. Conservation and Utilization of harmonious development seems more an idealization initiative. Ostensibly contradictory development and protection, in essence, a conflict of interest often reflects national, local and the public between.

\section{Protection of Cultural Heritage and Tourism Development}

In developed countries, as the scenic World Heritage Site and choose between economic efficiency and social effects is self-evident. They have adequate financial support, needs to be addressed is how to get more people on the basis of maximum protection to be able to enjoy these great legacy. While China and developing countries, the World Heritage still have to play the role of stimulating economic growth. This makes conservation difficult. Faced with such a contradiction, we still have to firmly put the protection in the first place. If the decision-makers, managers in various fields protectors, developers and even the masses able to reach this consensus, the contradiction between heritage protection and tourism development is no longer a problem.

For the change of legacy business model and property from the bow \{Debates gradually form two melody. One is from the heritage attributes of property rights concept, the United States transplant advocates national park management system, referred to as a national park on; the other is from the relationship between the heritage tourism market, proposed the separation of ownership and management heritage, so Heritage tour operators follow the market mechanism, referred to as the transfer of the right to operate on. The starting point of two kinds of proposition all have their own rationality. On the Chinese National Park Heritage Management transplant advocates US national park management system, and its essence is to protect outstanding. In the current practice of Chinese heritage management reform, the real work is the transfer of the right to operate on. Practice on the transfer of the right to operate in the creation of economic benefits, but also cause serious damage to the heritage and the profit-driven practitioners, greatly increases the potential extent of the damage. On the National Park theoretically in favor of heritage protection, but in practice and out of touch with China's national conditions. Seen two kinds of ideas we are different, they are not perfect. The focus of controversy is that both heritage conservation and the use of 
binding determined point, the specific performance of system selection Heritage Protection and Heritage Tourism Development.

Establish a mechanism for the supervision and management of the relevant government officials and managers make decisions supervision. Disregard for national policies and regulations, the blind pursuit of performance and economic interests to make the wrong decision, resulting in the destruction of heritage staff should be given severe punishment.

As described above, a development of rational conservation planning and tourism planning, but also to develop coordinated conservation and tourism planning. To assist the development of the local style, the aim is to maximize the tourists face history. While the maximum to avoid resort commercialization.

Of Heritage quantify monitor sustainable development. For capacity control, including the number of visitors, the carrying capacity of a historic building or structure, the number of various kinds of tourism service facilities, hydroelectric energy consumption, waste disposal capacity, to avoid excessive use of heritage sites.

Protection have the economic support, tourism development should start-up capital. Access to funds not only has to rely on government investment, but also rely on community and civil power. About sources of funding, the general routine of four channels: First, government funding; Second, community funds, donations; the third is bank loans; Fourth, after the return of tourism revenue. In addition, access to finance should be reasonable distribution and effective use.

In addition to improving the protection of the heritage disciplines, strengthen basic research, but also efforts to train heritage conservation and tourism management talents. In addition to developing their professional knowledge, but also cultivate their love emotional heritage. The only way for the people to the cause of protecting our heritage dedication that heritage play its due role.

First, let people really know what is heritage, what kind of behavior is to protect heritage? How it will cause damage, so that people on how to develop and how to develop tourism there criteria. Second, to raise awareness of heritage protection is the first one, when the development of tourism and heritage protection in conflict can not be resolved, should first meet the requirements of heritage protection. To establish a correct concept widely, the most important work is education. First, to raise awareness of leading officials, recognizing the value of heritage and responsibilities entrusted to it; educate specifically involved in the protection of heritage art; educate tourism practitioners; and educational heritage to residents and tourists. Heritage Education teenagers from starting to the relevant intellectual heritage incorporated into textbooks, so they were trained to understand the importance of heritage protection, conservation efforts can be passed along from generation to generation.

\section{Conclusion}

This paper is to stand in the perspective of cultural heritage protection and utilization of sustainable development, a useful discussion of cultural heritage tourism development appropriate mode. The ultimate goal is to develop strategies for sustainable development. First and foremost is the overall understanding of the development and protection. Sustainable development emphasizes the protection, but the restrictions on development are not unconditional. Human development of any development strategy and its implementation of its push, only a fundamental objective is to promote the progress of human society as a whole, it is understood that sustainable development strategies need to recognize the premise. Sustainable development strategy is the continuous development of human society from the process of looking, made effective use of resources, improve the environment, promote a virtuous cycle of development model of social and economic development, therefore, it does not emphasize the speed of regional development, and that emphasize human development and coordination of natural ecosystems as well as self-development. Therefore, natural heritage, cultural heritage and other resources to implement the sustainable development strategy is not entirely passive protection, meticulously left to future generations to enjoy, but should be in the current economic development, promote the progress of human civilization, as the economy gradually develop technical conditions, the ability to more natural and cultural resources for 
development.

\section{References}

[1] Hyung Yu. Park Shared national memory as intangible heritage: Re-imagining Two Koreas as One Nation Annals of Tourism Research, 2001.

[2] Ramsey. D, Everitt. J. If you dig it, they will come, Archaeology heritage sites and tourism development in Belize, Central America [J] .Tourism Management, 27.11: 1-5.

[3] Antonio, P. R. The Vicious Circle of Tourism Development In Heritage Cities Annals of Tourism Research, 22, 29 (1): 165-182.

[4] Simons, Michael S. Aboriginal Heritage Art and Moral Rights Annals of Tourism, 2, 27 (2):. 412-431,

[5] Ondimu, Kennedy: Cultural Tourism in Kenya Annals of Tourism Research, 22, 29 (4): 136-147.

[6] Yandiver pame la. B. Craft knowledge as an intangible cultural property: A case study of Smart and tiles and traditional potters in Uzbekistan, Museum International, 24, 56 (2): 81-89. 